\title{
Importance of paying the producer according to the Quality of their Milk
}

\author{
Bailone RL ${ }^{1,2 *}$, Roça RO ${ }^{2}$, Borra RC ${ }^{3}$, Fukushima HCS ${ }^{3}$ and Aguiar L ${ }^{4}$ \\ ${ }^{1}$ Ministry of Agriculture, Livestock and Supply, Federal Inspection Service, São Carlos, SP, Brazil \\ ${ }^{2}$ Department of Animal Breeding and Nutrition, Paulista State University, Botucatu, SP, Brazil \\ ${ }^{3}$ Department of Genetics and Evolution, Federal University of São Carlos, São Carlos, SP, Brazil \\ ${ }^{4}$ Department of Food Technology and Innovation, Harper Adams University, Newport, UK
}

Submission: May 16, 2019; Published: May 31, 2019

*Corresponding author: Bailone RL, Ministry of Agriculture, Livestock and Supply, Federal Inspection Service, São Carlos, Brazil

\section{Mini Review}

In recent years, dairy companies have become more concerned with the quality standard of quality raw milk supplied by farmers. Due to increased differences in product quality between producers there is a wide range in milk solids' composition (protein, fat, lactose), and microbiological parameter, as Somatic Cell Count (SCC) and Standard Plate Count (SPC). Bailone et al. (2017) found a significant mean variation in buffalo milk parameters in twelve farms in Brazil (Amplitude: Protein 3.7-4.4\%; Fat 5.1-6.9\%; Lactose $4.7-5.0 \%$; SCC $47 \times 10^{3}-168 \times 10^{3}$ cells/mL; SPC $125 \times 10^{3}$ $9999 \times 10^{3} \mathrm{CFU} / \mathrm{mL}$ ) among all dairy farms studied. It proved the existence of quality differences between milk suppliers, and to address this a price incentive initiative which remunerated farmers for higher raw milk quality could be a sound strategy for dairy processing companies over favoring yield alone.

Such a practice is also already in place in other countries such as the USA, Canada, New Zealand, Costa Rica, Brazil, India, China, Indonesia, Vietnam, Zimbabwe, Kenya, among others. Milk processors in these countries have adopted a payment system which incentives quality which has returned good results regarding the improvement of quality and competitiveness of the dairy sector [1-7]. The differentiated payment scheme can be implemented using either the analysis of composition parameters or microbiological parameters. It thus penalizes those farmers who do not want to adhere to the scheme, by the means of monetary loss, as well as transfer the responsibility to improve products' reliability from the milk processor. Often, the penalties are implemented via temporarily delisting a milk supplier or by direct deduction of payment $[2,5]$. A payment incentive based on the milk's composition can also be felt on the quality and yield of its derivatives, such as cheese. In the case of dairy companies in the Netherlands and Denmark, spearheads in the dairy sector, they have been paying for the protein content over three decades. When considering the value adding to milk where a large percentage of it is intended for the preparation of cheeses, milk powder, casein or caseinates the payment on its protein and fat content composition has been an essential practice. It is worth noting that in countries such as Costa Rica and Spain, rather than considering the protein content, the payment is done based on its dry extract [5].

Furthermore, the milk's payment scheme can be based on hygiene and health of the herd through the analysis of SPC (reflecting management practices and hygiene techniques), and SCC (health of the herd). Despite this, other tests can be also performed in a complementary manner, such as coliforms, sediment, colostrum (especially in the first three weeks of lactation), cryoscopy, among others. Hence, quality payment programs can financially encourage the producer to provide better quality milk [5] too. In the case of Denmark, payment based on hygiene quality is determined in four categories, of which the second category (less than 100,000 pathogens) determined the base price. Top milk quality (less than 30,000 pathogens) a premium of $2.5 \%$ in value is given to producers, and for lower quality milk a deduction is imposed. In other countries, benefits are only granted to those who produce in the higher threshold, whilst inferior milk quality grade does not attract any deductions. In New Zealand, deductions are only applied from the base price for hygienic quality [5]. Countries such as the United States and Canada also work with systems that remunerate for the quality of refrigerated raw milk. In Canada, fat, protein and somatic cell counts are checked, and a higher value given for protein $[6,7]$.

Within the EU, the quality payment system currently subsidizes liquid milk within pre-set parameters and penalizes those below standard [4]. A milk price formula considers the bactoscan, butter fat, protein, SCC and volume (A\&B contracts) [8]. A\&B contracts are based on volume delivered according to seasonal analysis and projections, which are affected by region and type of climate. The milk contract relates to the desired parameters 
and milk quality is verified by accredited laboratories. Producers are assisted to improve milk quality by technical staff when part of contract schemes with retailers and milk processors [4,9-10]. Food sustainability and safety has increasing in importance for many internationally trade commodities such as in the case of coffee, and likewise, milk payments might be based on farmers adhering to sustainable practices still yet to be disseminated to other regions worldwide.

\section{References}

1. Caetano FM (2016) Análise da influência dos parâmetros de qualidade sobre a remuneração dos produtores de leite. 2016. 100 f. Dissertação (Mestrado em Gestão Organizacional) - Universidade Federal de Goiás, Catalão, Brazil.

2. Foreman I, Leeuw BD (2013) Quality Based Milk Payment Study Kenya Dairy Sector for SNV KDMP Project.

3. Botaro BG, Gameiro AH, Santos MV (2013) Quality based payment program and milk quality in dairy cooperatives of Southern Brazil: an econometric analysis. Scientia Agricola 70(1): 21-26.
4. Pinheiro FF (2010) Remuneração como incentivo à qualidade do leite. IV Congresso Brasileiro da Qualidade do Leite. Conselho Brasileiro de Qualidade do Leite. Florianópolis.

5. Ibarra AA (2008) Sistema de pagamento do leite por qualidade - visão global.

6. Machado PF (2008) Pagamento do leite por qualidade. In: Barbosa SBP, Batista AMV, Monardes H (Eds.), III Congresso Brasileiro de Qualidade do Leite. Recife: CCS Gráfica e Editora 1: 183-191.

7. Monardes H (1998) Programa de pagamento de leite por qualidade em Quebéc, Canadá. In: Simpósio Internacional sobre Qualidade do Leite. Anais. Curitiba, Brazil, UFPR 88: 40-43.

8. AHDB (2018) Milk price calculator and contracts.

9. Fonterra (2017) Fonterra Farmers' Handbook 2016/2017.

10. Bailone RL, Borra RC, Roça RO, Aguiar LD, Harris M (2017) Quality of refrigerated raw milk from buffalo cows (Bubalus bubalis bubalis) in different farms and seasons in Brazil. Ciência Animal Brasileira 18: $1-12$.

\section{Your next submission with Juniper Publishers will reach you the below assets}

- Quality Editorial service

- Swift Peer Review

- Reprints availability

- E-prints Service

- Manuscript Podcast for convenient understanding

- Global attainment for your research

- Manuscript accessibility in different formats

( Pdf, E-pub, Full Text, Audio)

- Unceasing customer service

Track the below URL for one-step submission https://juniperpublishers.com/online-submission.php 